\title{
Finite Element Method Analysis Applied to Different Foundations Structures Systems
}

\author{
Guillaume Hervé Poh'sie, Linda Kevine Guiameugne Guabiapsie, Gabrielle Laure Djeukoua \\ Nathou, Giuseppe Cardillo, Carmelo Majorana
}

\begin{abstract}
In the conventional static analysis of building frames, the base is idealised on rigid supports and the building is subdivided into three parts namely, the superstructure, the foundation and the ground soil, before design. In real life situations, the soil underneath the building undergoes deformations which may alter the performance of the structure. In this paper, it is studied the effect of soil type and foundation type on the response of a building frame system with both fixed base and flexible base. The Winkler model of soil-structure interaction is adopted to study the influence of soil flexibility and foundation rigidity on a 4 storey $R C$ building with a regular plan resting on three types of soils namely, the light peat marshy ground, wet clay and medium gravel with fine sand. Three types of foundations are considered in the study: isolated footings, tied foundation and the raft (with and without overhangs) foundations. Winkler model is developed using springs by Finite Element Method in SAP2000. The settlement, the bending moment, the shear force and the axial force are the parameters placed forth for the comparative study. Results obtained reveal an increase in the response of the structure with respect to the soil flexibility and foundation rigidity.
\end{abstract}

Keywords: Isolated footing, tied foundation, raft foundation, soil-structure interaction, spring stiffness, settlement

\section{INTRODUCTION}

The rapid urbanisation and increase in population have led to construction of buildings on all types of soils. In the past such constructions were considered unsuitable and so, structural analysis was limited to a simplified model where, the building was considered on fixed supports (separately from the foundation) and design. Today with the advent of sophisticated computer programs which makes it possible to take into account soil deformation, structural analysis of a building with fixed supports is proven not effective, especially when construction is supposed to be on soft soil.

Manuscript received on July 22, 2021.

Revised Manuscript received on August 23, 2021.

Manuscript published on August 30, 2021.

* Correspondence Author

Dr. Eng. Guillaume Hervé poh'sie*, Assistant Lecturer, Department of Structural Civil Engineer, College of Technology, University of Buea, Cameroon. Email : pguillaumeherve.ing@gmail.com

Eng. Linda Kevine Guiameugne Guabiapsie, Department of Civil Engineering, National Advanced School of Public Works of Yaounde, Cameroon.

Eng. Gabrielle Laure Djeukoua Nathou, Departement of civil engineering, National Advanced School of Engineering of Douala, Cameroon.

Eng. Giuseppe Cardillo, Assistant Professor, Department of Civil, Environmental and Architectural Engineering, University of Padua, Italy

Prof. Carmelo Majorana, Professor, Structural Mechanics and Engineering, University of Padua, Italy.

(C) The Authors. Published by Blue Eyes Intelligence Engineering and Sciences Publication (BEIESP). This is an open access article under the CC BY-NC-ND license (http://creativecommons.org/licenses/by-nc-nd/4.0/)
Many researchers have shown the prominence of structural analysis integrated to the study of settlements. This type of analysis provides according to Velloso et al., 1998 [7]. the real displacements of the foundation and of the structure (with its internal effort) when it is included in the analysis Most of these studies are based on the behaviour of the structure with respect to soil flexibility, neglecting the rigidity aspect of the infrastructure (type of foundation).

\section{AIM OF THE STUDY}

The aim of this study is to find out the influence of soil flexibility and foundation rigidity on the structural behaviour of a RC framed structure with a regular plan. To achieve this goal, the Winkler method of soil-structure interaction is considered.

\section{STUDY METHODOLOGY}

Two cases are considered for this study. In the first case, the building is modelled with isolated footings on different types of soils namely, medium gravel with fine sand, wet clay and light peat marshy ground. In the second case, the building is modelled with different types of foundations namely isolated footings, tied foundation and raft foundations, all on light peat marshy ground. The parameter required for the analysis is the modulus of subgrade reaction tabulated in Table 3.1 for the different soil types.

Table III.1. Values of the modulus of subgrade reaction for different soil types

\begin{tabular}{|c|c|l|}
\hline Soil type & $\begin{array}{c}\text { Subgrade } \\
\text { reaction (C) }\end{array}$ & Unit \\
\hline $\begin{array}{c}\text { Light peat marshy } \\
\text { ground }\end{array}$ & 5000 & $\mathrm{kN} / \mathrm{m}^{3}$ \\
\hline Wet clay & 40000 & $\mathrm{kN} / \mathrm{m}^{3}$ \\
\hline $\begin{array}{c}\text { Medium gravel with } \\
\text { fine sand }\end{array}$ & 120000 & $\mathrm{kN} / \mathrm{m}^{3}$ \\
\hline
\end{tabular}

The building is a symmetric frame system of 5 bays by 3 bays-4 storeys, regular in plan and in elevation as shown in Figure 3.1. The beams all have rectangular sections of 35 $\mathrm{cm}$ width by $50 \mathrm{~cm}$ height, the columns have square sections of $35 \mathrm{~cm}$ width by $35 \mathrm{~cm}$ height. The beams are spaced $4 \mathrm{~m}$ apart following the $\mathrm{x}$-direction and $6.2 \mathrm{~m}$ following the $\mathrm{y}$ direction. The foundation is at a depth of $1.2 \mathrm{~m}$ below the ground level, the ground floor is $3.5 \mathrm{~m}$ high, the next two floors are $3.2 \mathrm{~m}$ high and the last floor is $3 \mathrm{~m}$ high. The building serves for residential purpose, and the loads are linear gravity loads applied on the beams.

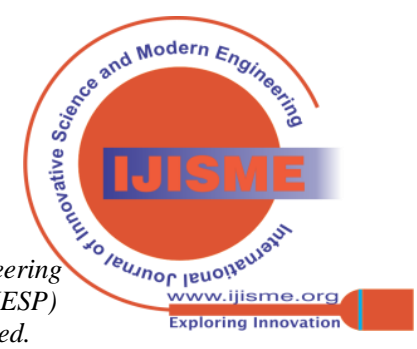




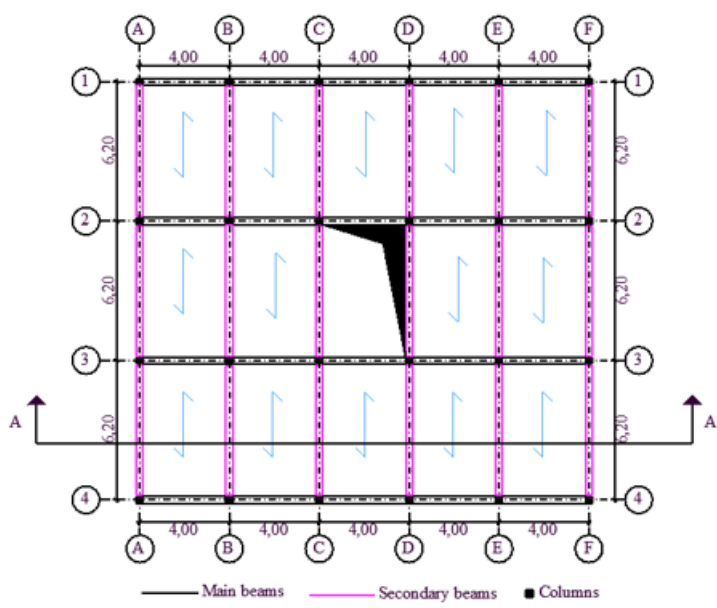

(a)

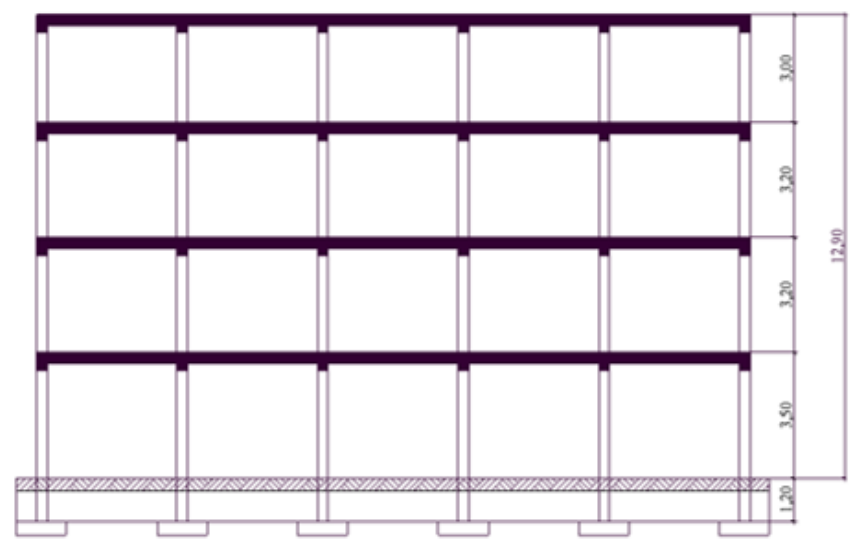

(b)

Figure III.1. Regular plan of the building (a) and section A-A (b)

\subsection{Numerical modelling}

The building is modelled with fixed base supports in one hand and with foundations modelled as shell elements in the other hand. The beams and the columns are modelled as frame elements having 2 nodes with 6 degree of freedom at each node while the foundation is modelled as shell element having 4 nodes with 6 degree of freedom at each node. The foundation is then meshed with a maximum mesh size of 0.5 $\mathrm{m}$. The soil is idealised by considering identical springs with 6 degree of freedom. The soils are represented in the software as area or line springs depending on whether they are applied to a shell element or a frame element, respectively. The software automatically creates equivalent joints springs which represent the area and line springs which are assigned to an object. Spring stiffness at each joint is calculated from the modulus of subgrade reaction as follows.

$$
K_{s}^{v}=C \times A
$$

Where $A$ is the contributing area of the mesh

\subsection{Inclusion of soil-structure interaction}

The technique consists in analysing the structure with fixed (rigid) supports and then extracting the values of the support reactions in order to estimate the dimensions of the

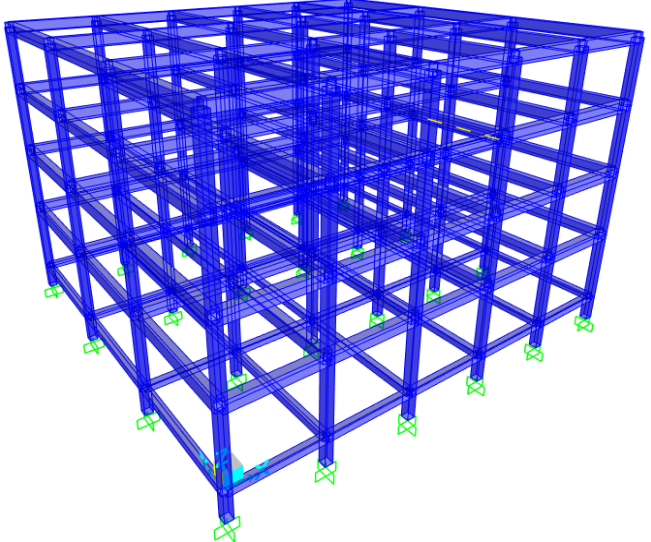

Model with fixed supports foundations, using the bearing capacity of the soil ( 0.2 $\mathrm{N} / \mathrm{mm}^{2}$ ). In new analyses, the rigid supports are replaced by foundations of defined sizes with area/line springs at the base, taking into account the type of soil on which the analysis is performed. The footings were grouped into classes based on the value of the support reaction below which they are found. The dimensions of the footings are presented in Table 3.2, that of the tie beams are similar to the beams of the superstructures and the raft foundation is a flat slab of thickness $50 \mathrm{~cm}$.

Table III.2. characteristics of the footing class of the structure

\begin{tabular}{|c|c|c|c|}
\hline $\begin{array}{c}\text { Footing } \\
\text { position }\end{array}$ & $\begin{array}{c}\text { Footing } \\
\text { class }\end{array}$ & Footing size & $\begin{array}{c}\text { Footing } \\
\text { thickness }\end{array}$ \\
\hline $\begin{array}{c}\text { Interior } \\
\text { footings }\end{array}$ & Class 3 & $\begin{array}{c}270 \mathrm{~cm} x \\
270 \mathrm{~cm}\end{array}$ & $50 \mathrm{~cm}$ \\
\hline $\begin{array}{c}\text { Exterior } \\
\text { footings }\end{array}$ & Class 2 & $\begin{array}{c}230 \mathrm{~cm} x \\
230 \mathrm{~cm}\end{array}$ & $40 \mathrm{~cm}$ \\
\hline $\begin{array}{c}\text { Corner } \\
\text { footings }\end{array}$ & Class 1 & $\begin{array}{c}170 \mathrm{~cm} \mathrm{x} \\
170 \mathrm{~cm}\end{array}$ & $30 \mathrm{~cm}$ \\
\hline
\end{tabular}

The different models for which the analyses are performed are presented as follows: in figure 3.2.

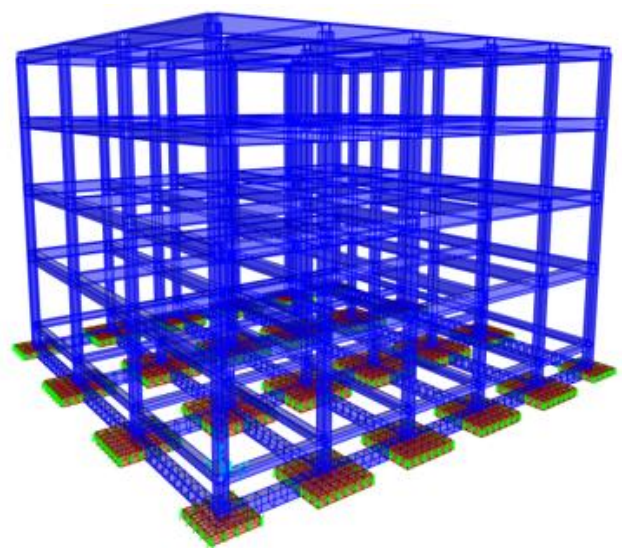

Model with tied foundation 


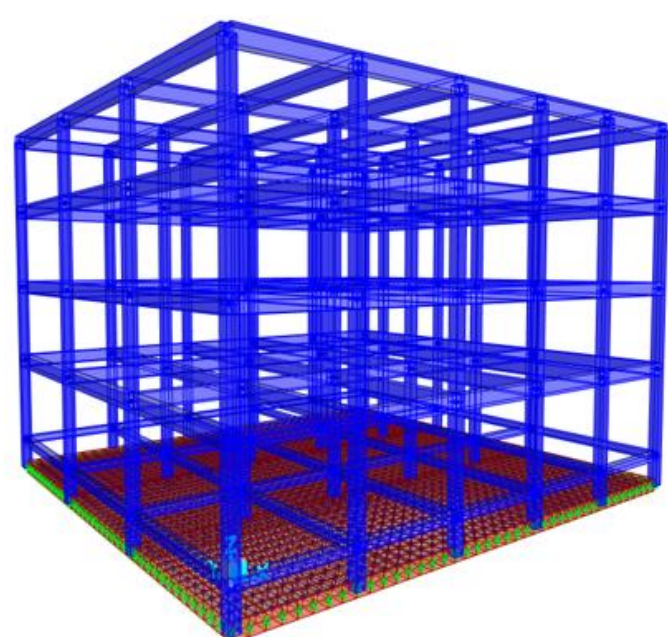

Model with raft without overhangs

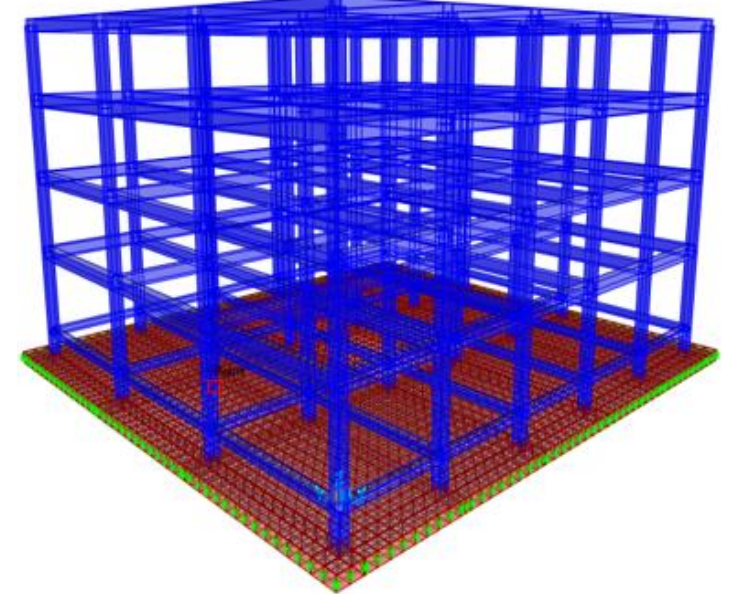

Model with raft with overhangs

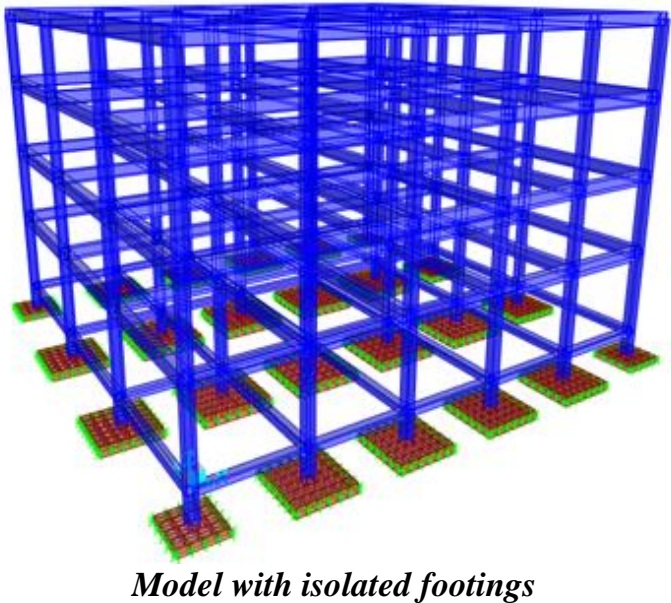

Figure III.2. Models from which the study are perform

\section{RESULTS FOR PARAMETRICAL STUDY}

For the study, was chosen: a longitudinal reference beam in the $\mathrm{x}$-axis, the most axially solicited column and the footing below that column. The effect of different soil types and foundation types are investigated considering and without considering soil-structure interaction. The results are presented as follows:

\subsection{Elastic settlement and structural deformation}

The variation of settlement of the foundation for a line of footings following the $\mathrm{x}$-direction, on different soil types is presented in Figure 4.1.

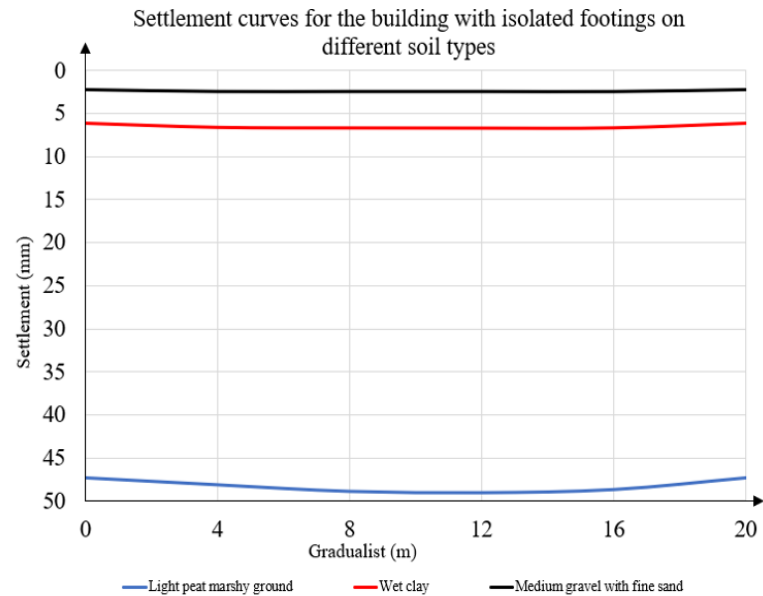

Figure IV.1. Foundation settlement on different soil types

From Figure 4.1, it is observed an increase in settlement as the soil flexibility increases. The settlement becomes quiet constant as the rigidity of the soil increases. The maximum value of the vertical structural deformation of the building on the different soils is summarised in Table 4.1.

Table IV.1. Values of the maximum structural deformation on different soil types

\begin{tabular}{|c|c|c|}
\hline Soil type & $\begin{array}{c}\text { Maximum } \\
\text { displacement } \\
\text { Uz }\end{array}$ & Unit \\
\hline $\begin{array}{c}\text { Light peat } \\
\text { marshy } \\
\text { ground }\end{array}$ & 53 & $\mathrm{~mm}$ \\
\hline Wet clay & 11 & $\mathrm{~mm}$ \\
\hline $\begin{array}{c}\text { Medium } \\
\text { gravel with } \\
\text { fine sand }\end{array}$ & 7 & $\mathrm{~mm}$ \\
\hline
\end{tabular}

Due to the fact that, an extremely high deformation was recorded for the building on light peat marshy ground, the building was analysed with two other types of foundations on this soil in order to reduced this deformation. The results of the analyses are summarised in Table 4.1.

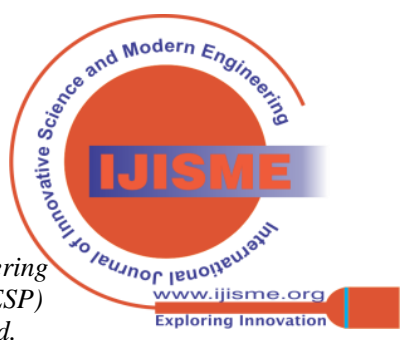


Table IV.2. Values of the maximum structural deformation for different foundation types

\begin{tabular}{|c|c|c|}
\hline $\begin{array}{c}\text { Foundation } \\
\text { type }\end{array}$ & $\begin{array}{c}\text { Maximum } \\
\text { displacement Uz }\end{array}$ & Unit \\
\hline $\begin{array}{c}\text { Isolated } \\
\text { footings }\end{array}$ & 53 & $\mathrm{~mm}$ \\
\hline Tied foundation & 25 & $\mathrm{~mm}$ \\
\hline $\begin{array}{c}\text { Raft without } \\
\text { overhangs }\end{array}$ & 28 & $\mathrm{~mm}$ \\
\hline $\begin{array}{c}\text { Raft with } \\
\text { overhangs }\end{array}$ & 21 & $\mathrm{~mm}$ \\
\hline
\end{tabular}

From Table 4.2, it is observed that as the rigidity of the foundation is increased (type of foundation changed), the vertical structural displacement is reduced. An exception is recorded with the raft without overhangs, which providing more rigidity than the tied foundation causes a lesser reduction. This can be explained by the fact that the pillars at the edges of the raft renders the structure less stable, by creating eccentricity.

\subsection{Beam moment}

The variation of bending moment in the beam for the building with fixed base and flexible base: for the building with isolated footings on different soil types and for the building with different foundation types on light peat marshy ground are present in Figure 4.2 and Figure 4.3 respectively.
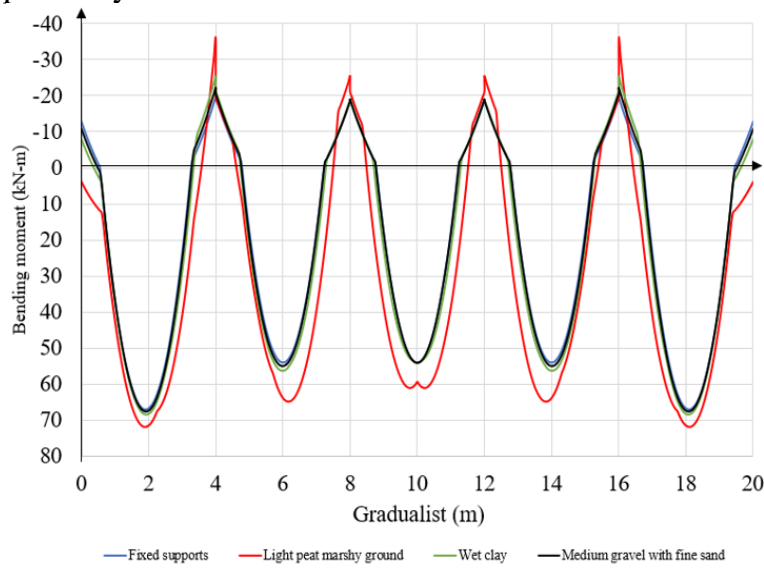

Figure IV.2. Beam bending moment for the building with isolated footings on different soil types

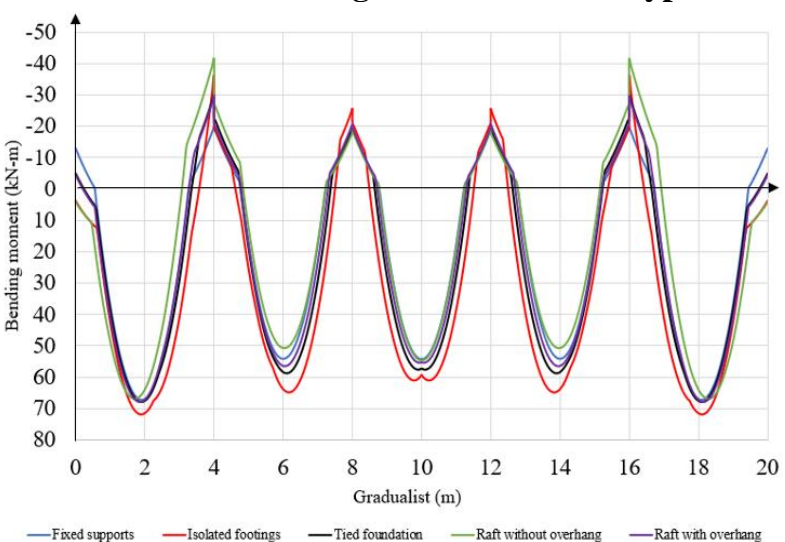

Figure IV.3. Beam bending moment for the building with different foundation types on light peat marshy ground

With reference to Figure 4.2, it is observed an increase in bending moment solicitation in the beam as the soil flexibility increase. In Figure 4.3 instead, the bending moment solicitation reduces as the rigidity of the foundation increases.

\subsection{Beam shear}

The variation of shear force solicitation in the beam for the building with fixed base and flexible base: for the building with isolated footings on different soil types and for the building with different foundation types on light peat marshy ground are present in Figure 4.4 and Figure 4.5 respectively.

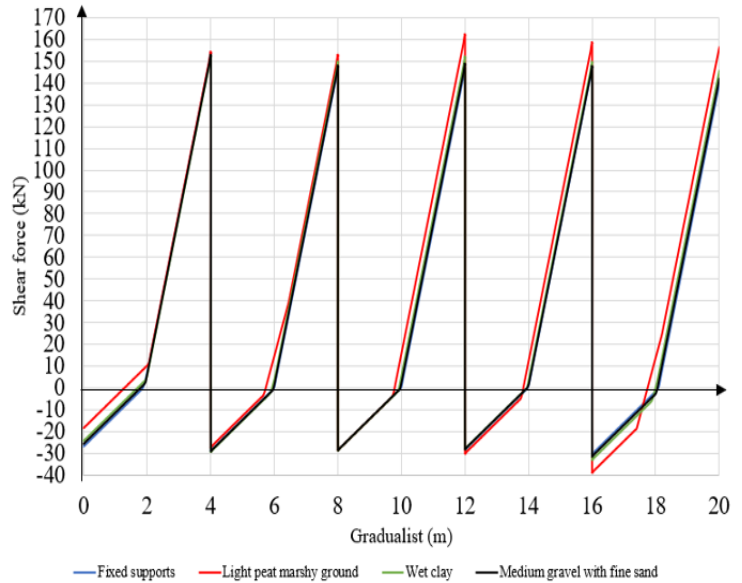

Figure IV.4. Beam shear force for the building with isolated footings on different soil types

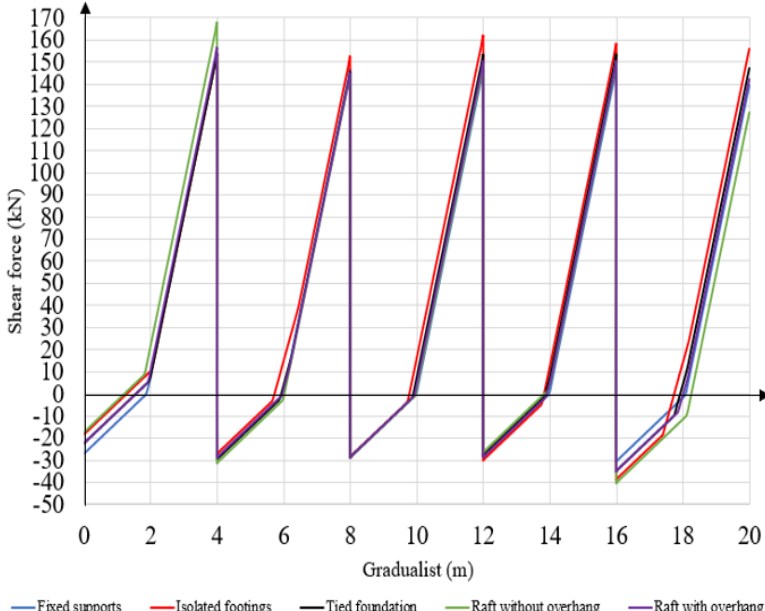

Figure IV.5. Beam shear force for the building with different foundation types on light peat marshy ground

From Figure 4.4, it is observed a reduction in shear force solicitation at the beam's midspan and an increase at the support for the first half of the beam, and an increase at the beam's midspan and a reduction at the support for the remaining half part of the beam as the soil flexibility increases. The reverse occurs as the foundation rigidity increases, as seen in Figure 4.5.

\subsection{Column moment}

The bending moment of the column for the building with isolated footings on different soil types in the $\mathrm{x}$-direction and the y-direction are presented in Figure 4.6. That for the building with different foundation types on light peat marshy ground both in the $\mathrm{x}$ and direction are presented in Figure 4.7.

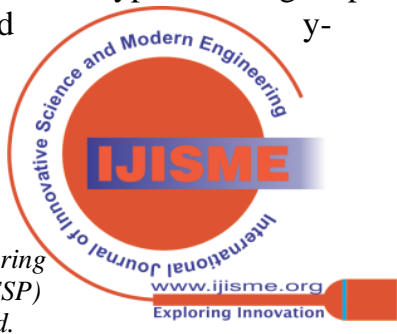




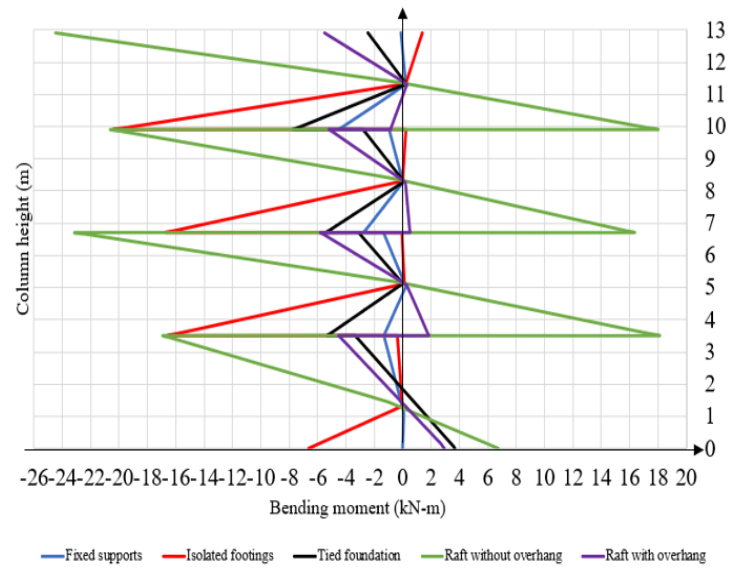

(a)

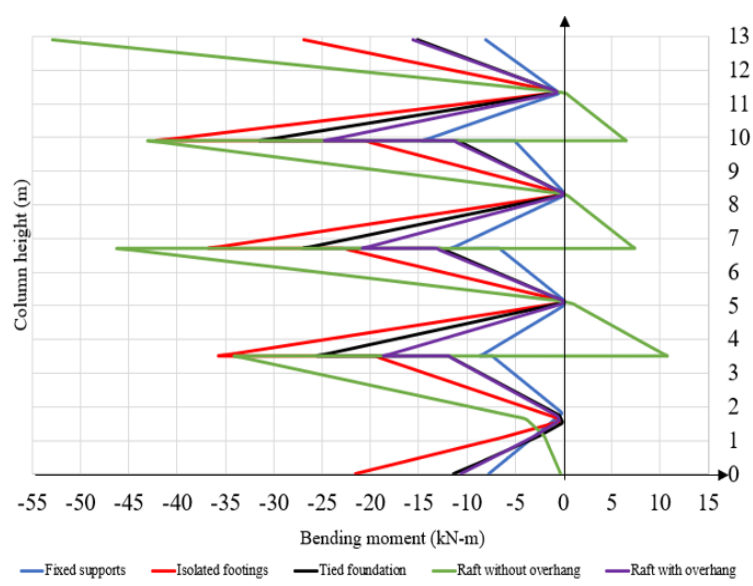

(b)

Figure IV.6. Column bending moment for the building with isolated footings on different soil types in the: (a) $\mathrm{x}$-axis and (b) y-axis

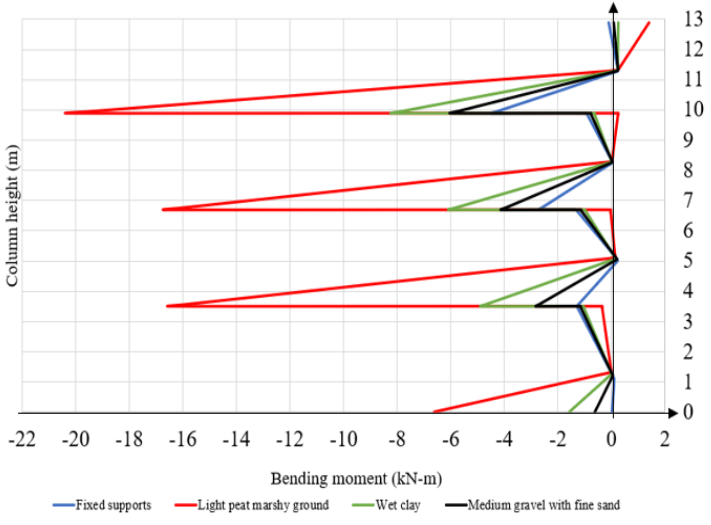

(a)

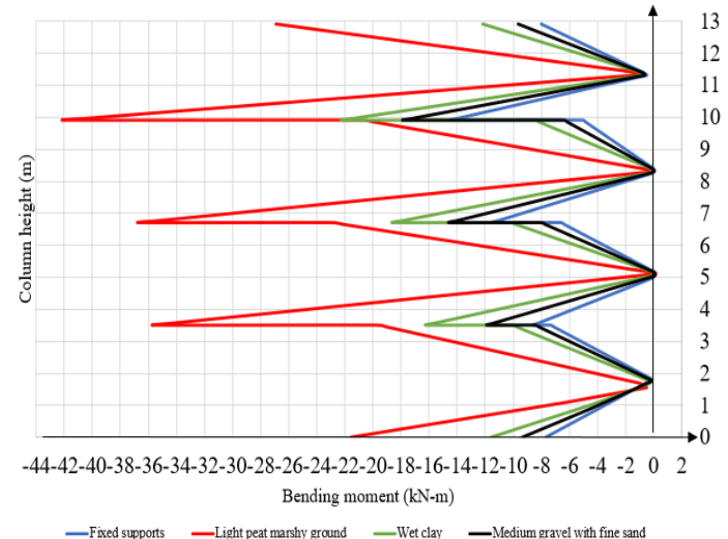

(b)

Figure IV.7. Column bending moment for the building with different foundation types on light peat marshy ground in the: (a) $x$-axis and (b) $y$-axis

From Figure 4.6, it is observed an increase in bending moment solicitation in the column as the soil flexibility increases. From Figure 4.7, the bending moment decreases as the rigidity of the foundation increases, except for the raft foundation case as already mentioned.

\subsection{Column axial force}

The variation of the axial force solicitation in the column for the building with isolated footings on different soil types and the building with different foundation types on light peat marshy ground are presented in Figure 4.8 and Figure 4.9, respectively.

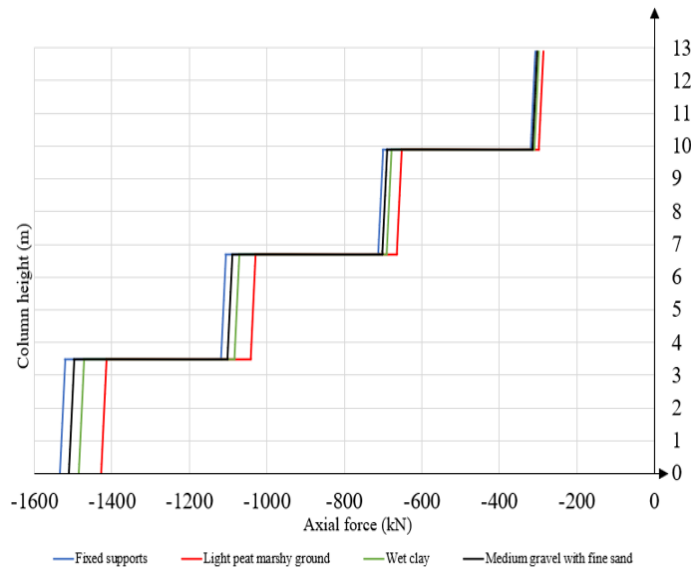

Figure IV.8. Column axial force for the building with isolated footings on different soil types

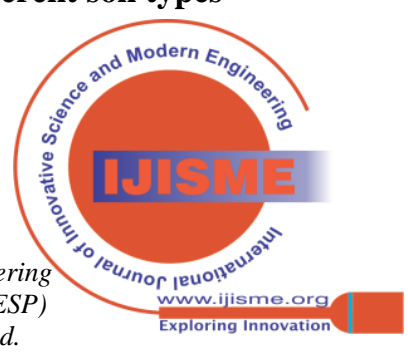




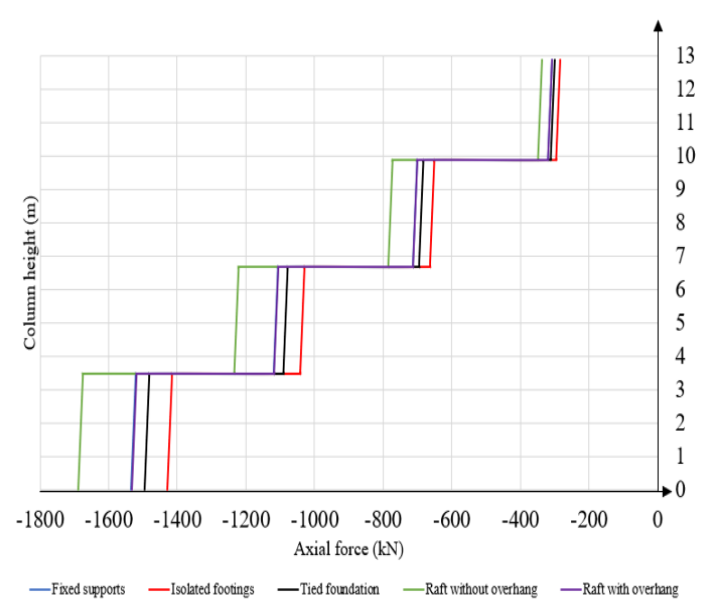

Figure IV.9. Column axial force for the building with different foundation types on light peat marshy ground

From Figure 4.8, it is observed a decrease in axial force in the column as the flexibility of the soil increases meanwhile, in Figure 4.9, it is observed an increase in axial force solicitation in the column as the rigidity of the foundation increase. Still an exception is observed for the building on the raft without overhangs.

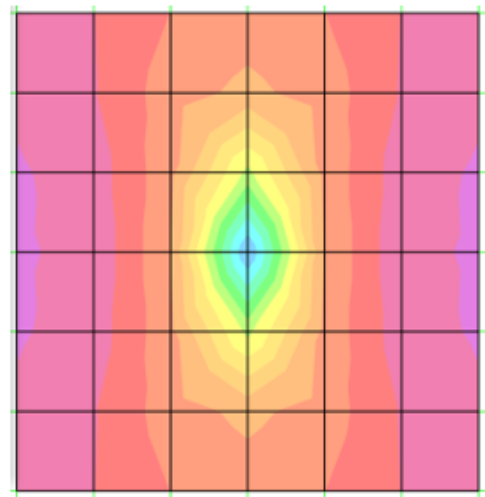

(a)

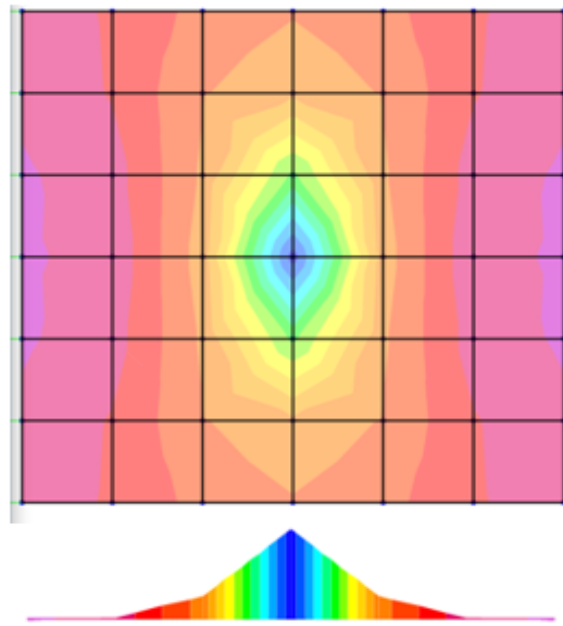

(c)

\subsection{Footing moment}

The variation bending moment in the isolated footing (in the $\mathrm{x}$-axis) for the building on different soil types are presented in Figure 4.10. A summary of the maximum bending moment in the footing for the building with fixed base and flexible base are presented in Table 4.3.

Table IV.3. Values of the maximum bending moment on a footing for the building on different soil types

\begin{tabular}{|c|c|}
\hline Soil type & $\begin{array}{c}\text { Maximum bending } \\
\text { moment (kN-m) }\end{array}$ \\
\hline Fixed support & 447.6 \\
\hline $\begin{array}{c}\text { Medium gravel with fine } \\
\text { sand }\end{array}$ & 423.5 \\
\hline Wet cay & 421.9 \\
\hline Light peat marshy ground & 407.1 \\
\hline
\end{tabular}

From Figure 4.10, it is observed a decrease in bending moment solicitation as the soil flexibility increases. These results are supported by the values presented in Table 4.3, which show a decrease in the maximum value of the bending moment in the footing as the flexibility of the soil is increased.

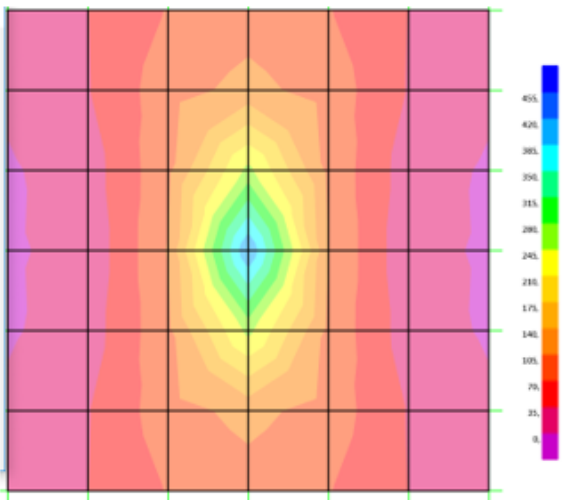

(b)

Figure IV.10. Footing bending moment for the building with isolated footings on: (a) medium gravel with fine sand, (b) wet clay and (c) light peat marshy ground

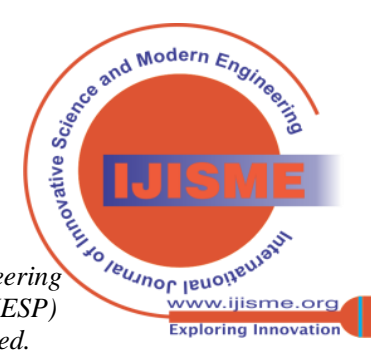




\section{CONCLUSION}

This paper presents the numerical analyses of foundations-structures systems using soil-structure interaction. SAP2000 is used as FEM tool for the analyses. Results obtained show that:

1) The value of the vertical deformation (settlement) of flexible shallow foundation can be determined through FEM modeling. Also, it was observed small differential settlements caused by the concordance between the soil deformation and the structure deformation.

2) Increasing the soil flexibility causes the beam moment and the column moment to increase while foundation moment decreases. Also, beam shear force decreases at midspan and increase at the supports for one half of the beam, and increase at midspan and decrease at the supports for the other half part of the beam. The column axial force decrease.

3) Increase foundation rigidity causes a reduction in settlement, reduced beam and column moments, increased column axial force, and increased beam shear force at the midspan and reduced at the support for one half of the beam and reduced beam shear force at midspan and increase at the support for the other half part of the beam. An exception was noticed with the raft without overhangs due to eccentricity of the columns at the edges, which reduced stability.

\section{REFERENCES}

1. $\quad$ BS EN 1992-1-1 2004, Eurocode 2: Design of concrete structures Part 1-1: General rules and rules for buildings, London, U.K

2. El Arabi I., El Gendy M. (2001). Optimum Design of Foundation Systems. Port Said Engineering Research Journal, Faculty of Engineering, Suez Canal University, Volume 5, No. 2, September 2001, pp. 456-473

3. J. E. Bowles, Foundation Analysis and Design, $\left(5^{\text {th }}\right.$ Edition, McGraw-Hill international book company, Tokyo, Japan, 1997)

4. Lakshmi Narasaiah, G. (2008). Finite Element Analysis. BS Publications (2008)

5. Magade, S.B., Ingle, R.K. (2019). Numerical Method for Analysis and Design of Isolated Footing Under Concentric Loading.

6. International Journal of Advanced Structural Engineering (2019) 11:9-20

7. Pavan, R.C., Costella, M.F., Guarnieri, G. (2014). Soil-structure Interaction for Frame Structures on Shallow Foundations. IBRACON Structures and Materials Journal • $2014 \cdot$ vol. $7 \cdot \mathrm{n}^{\circ} 2$

8. SAP2000®, Software manual, Copyright (C) Computers and Structures, Inc., 1978-2019

9. Timoshenko S, Woinowsky-Krieger S (1959) Theory of Plates and Shells, 2nd edn. McGraw-Hill book Company, Singapore

10. V. Garag, Mrs. S. Karuna. Effect of Soil-Structure Interaction on Regular and Irregular, Medium RC Framed Structure. International Journal of Science, Engineering and Technology Research (IJSETR) Volume 5, Issue 5, May 2016. ISSN: 2278 - 7798

\section{AUTHORS PROFILE}

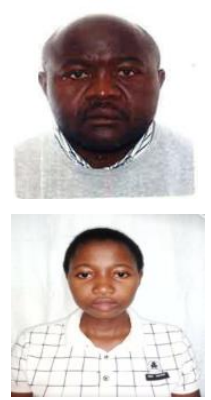

Guillaume Herve POH'SIE, Cameroonian, Assistant Lecturer, Structural Civil Engineer, at the College of Technology (University of Buea Cameroon) department of Mechanical Engineering.

Eng. Linda Kevine GUIAMEUGNE GUABIAPSIE, Cameroonian, Structural Civil Engineer at Nachtigal dam project Cameroon

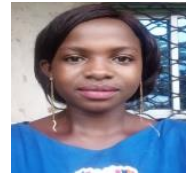

Gabrielle Laure DJEUKOUA NATHOU, Cameroonian, Structural Civil Engineer at Nachtigal dam project Cameroon

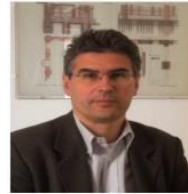

Giuseppe CARDILLO, Italian, Structural civil Engineer, assistant professor of Structural Mechanics at the University of Padua.

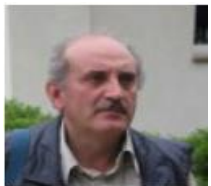

Carmello MAJORANA, Italian, full Professor of Structural Mechanics and Engineering at the University of Padua

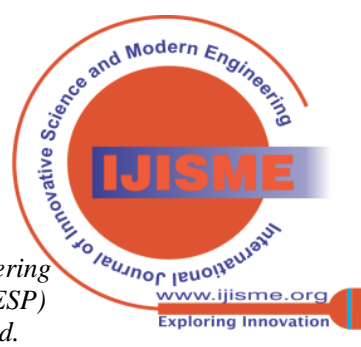

